AperTO - Archivio Istituzionale Open Access dell'Università di Torino

\title{
EvaGreen Real-time PCR protocol for specific 'Candidatus Phytoplasma mali' detection and quantification in insects
}

\section{This is the author's manuscript}

Original Citation:

Availability:

This version is available http://hdl.handle.net/2318/142324

since 2016-07-06T12:20:19Z

Published version:

DOI:10.1016/j.mcp.2013.02.001

Terms of use:

Open Access

Anyone can freely access the full text of works made available as "Open Access". Works made available under a Creative Commons license can be used according to the terms and conditions of said license. Use of all other works requires consent of the right holder (author or publisher) if not exempted from copyright protection by the applicable law. 


\section{(4) \\ UNIVERSITÀ DEGLI STUDI DI TORINO}

This Accepted Author Manuscript (AAM) is copyrighted and published by Elsevier. It is posted here by agreement between Elsevier and the University of Turin. Changes resulting from the publishing process such as editing, corrections, structural formatting, and other quality control mechanisms - may not be reflected in this version of the text. The definitive version of the text was subsequently published in [Molecular and Cellular Probes, 27 (2013),doi:http://dx.doi.org/10.1016/j.mcp.2013.02.001 ].

You may download, copy and otherwise use the AAM for non-commercial purposes provided that your license is limited by the following restrictions:

(1) You may use this AAM for non-commercial purposes only under the terms of the CC-BY-NC-ND license.

(2) The integrity of the work and identification of the author, copyright owner, and publisher must be preserved in any copy.

(3) You must attribute this AAM in the following format: Creative Commons BY-NC-ND license (http://creativecommons.org/licenses/by-nc-nd/4.0/deed.en), [+ Digital Object Identifier link to the published journal article on Elsevier's ScienceDirect ${ }^{\circledR}$ platform] 


\title{
EvaGreen Real-time PCR protocol for specific 'Candidatus Phytoplasma mali' detection and quantification in insects
}

\author{
M. Monti ${ }^{a}$, M. Martinib ${ }^{b}$, R. Tedeschii, ${ }^{a, *}$ \\ a Dipartimento di Scienze Agrarie, Forestali e Alimentari (DISAFA), University of Torino, Via Leonardo da \\ Vinci 44, 10095 Grugliasco (TO), Italy \\ ${ }^{b}$ Department of Agricultural and Environmental Sciences, University of Udine, Via delle Scienze 206, 33100 \\ Udine, Italy
}

\begin{abstract}
In this paper the validation and implementation of a Real-time PCR protocol based on ribosomal protein genes has been carried out for sensitive and specific quantification of 'Candidatus ( $\mathrm{Ca}$.) Phytoplasma mali' (apple proliferation phytoplasma, APP) in insects. The method combines the use of EvaGreen ${ }^{\circledR}$ dye as chemistry detection system and the specific primer pair rpAP15f$\mathrm{mod} / \mathrm{rpAP} 15 \mathrm{r} 3$, which amplifies a fragment of $238 \mathrm{bp}$ of the ribosomal protein $\mathrm{rplV}(\mathrm{rpl} 22)$ gene of APP. Primers specificity was demonstrated by running in the same Real-time PCR ' $C a$. Phytoplasma mali' samples with phytoplasmas belonging to the same group (16SrX) as ' $\mathrm{Ca}$. Phytoplasma pyri' and 'Ca. Phytoplasma prunorum', and also phytoplasmas from different groups, as 'Ca. Phytoplasma phoenicium' (16SrIX) and Flavescence dorée phytoplasma (16SrV). 'Ca. Phytoplasma mali' titre in insects was quantified using a specific approach, which relates the concentration of the phytoplasma to insect $18 \mathrm{~S}$ rDNA. Absolute quantification of APP and insect $18 \mathrm{~S}$ rDNA were calculated using standard curves prepared from serial dilutions of plasmids containing $r p l V$-rpsC and a portion of $18 \mathrm{~S}$ rDNA genes, respectively. APP titre in insects was expressed as genome units (GU) of phytoplasma per picogram (pg) of individual insect 18S rDNA. 'Ca. Phytoplasma mali' concentration in examined samples (Cacopsylla melanoneura overwintered adults) ranged from $5.94 * 10^{2}$ to $2.51 * 10^{4} \mathrm{GU} / \mathrm{pg}$ of insect $18 \mathrm{~S}$ rDNA. Repeatability and reproducibility of the method were also evaluated by calculation of the coefficient of variation (CV\%) of GU of phytoplasma and pg of $18 \mathrm{~S}$ rDNA fragment for both assays. CV less than 14\% and $9 \%$ (for reproducibility test) and less than 10 and $11 \%$ (for repeatability test) were obtained for phytoplasma and insect qPCR assays, respectively. Sensitivity of the method was also evaluated, in comparison with conventional 16S rDNA-based nested-PCR procedure. The method described has been demonstrated reliable, sensitive and specific for the quantification of ' $\mathrm{Ca}$. Phytoplasma mali' in insects. The possibility to study the trend of phytoplasma titre in the vectors will allow a deepen investigation on the epidemiology of the disease.
\end{abstract}


Keywords: 'Candidatus Phytoplasma mali', Real-time PCR, EvaGreen ${ }^{\circledR}$ dye, ribosomal protein gene, insects.

\section{INTRODUCTION}

Phytoplasma diseases are a group of severe plant disorders caused by obligate, cell wall-less bacteria, which are responsible of important yield losses in many crops worldwide [1,2], including ornamental plants and fruit crops.

Before the application of molecular biology as a tool in phytoplasma detection, the first approaches were mainly based on the observation of symptoms caused by different strains and the observation of the phytoplasma presence in sections of phloem tissues by electron microscopy [3]. However, many issues in phytoplasma detection can occur making difficult a correct phytoplasma diagnosis. They can include an unbalanced distribution of the phytoplasma in plant organs as well as the recovery phenomenon and a low concentration (especially in field-collected samples where the amount of phytoplasma DNA is less than $1 \%$ of the total amount of plant DNA) $[4,1]$.

Therefore, the application of PCR assays in the early 1990s, in particular, the use of a nested-PCR approach, allowed the establishment of a more sensitive, specific and faster approach for the detection of different species and strains of phytoplasmas in both plants and insects using generic and specific primers based on conserved sequences (e.g. 16S rRNA, ribosomal protein (rp), tuf, 16S-23S rRNA intergenic spacer region sequence) [3].

Although the use of nested-PCR remains a sensitive tool for phytoplasma detection, possibilities of cross-contamination between the two amplifications, as well as time-consuming post-amplification steps, were overcome by the introduction of a Real-time PCR approach. These assays increased the accuracy and sensitivity of pathogen detection. However, the choice of the appropriate chemistry detection system is a critical point during the establishment of a Real-time PCR experiment. This assay, which permits the detection and quantification of specific targets of DNA, is based on the use of labeling systems for the DNA amplicons. Most of these systems use probes labeled with a fluorescent dye (such as TaqMan ${ }^{\circledR}$ probes) which bind specifically a target sequence of the amplicons, while others, called DNA dyes, bind the minor groove of all double strand DNA molecules. The first technology results very sensitive but also expensive. Furthermore, for those template sequences that tend to vary, this system might generate false negatives due to the base pair mismatches between the probe and the specific region [5,6]. This problem does not occur 
when DNA dyes are used. This chemistry results less expensive and easier to use (because it does not require the design of a probe). However the detection of false positives might occur because of the non-specific binding capacity. To overcome this problem, melting curve analyses of each amplicon are necessary, in particular for those DNA samples extracted from woody plants collected from the field, and also from insect vectors [7] where the phytoplasma titre can be very low [1]. In those cases, the low concentration of the sample DNA results in very high threshold cycles $\left(\mathrm{C}_{\mathrm{T}}\right)$, which correspond also to the $\mathrm{C}_{\mathrm{Ts}}$ of non-specific DNA binding that can occur, resulting in the detection of false negatives [8,9]. Between the wide variety in commerce, most of the Real-time PCR approaches are based on the use of SYBR ${ }^{\circledR}$ Green I as DNA dye. SYBR ${ }^{\circledR}$ Green I is a high specific dye but its use has been shown to have some disadvantages, such as the inhibition of PCR reactions at high concentration [10,11], negative effect on DNA melting temperature [10,12], and preferential binding to GC-rich DNA sequences [12]. An alternative DNA dye is the EvaGreen ${ }^{\circledR}$, which has been demonstrated having a higher reaction efficiency at different concentration as well as better melting curves with sharper peaks compared with the SYBR Green chemistry [13].

The most important fruit tree phytoplasmas in Europe belong to the 16SrX-group, also called apple proliferation group, which includes the apple proliferation phytoplasma (APP) 'Candidatus (Ca.) Phytoplasma mali' (16SrX-A, the causal agent of apple proliferation, AP), 'Ca. Phytoplasma prunorum' (16SrX-B, the causal agent of European Stone Fruit Yellows, ESFY) and 'Ca. Phytoplasma pyri' (16SrX-C, the causal agent of Pear Decline, PD) [14-17].

In the specific, AP is an endemic disease, which affects apple trees in central Europe, with important economical losses in particular in Germany and Italy [18]. The infected plants show typical symptoms that are consequences of the presence, multiplication, and spread of the phytoplasma in the phloematic cells. Most of the symptoms involve both plants and fruits, like witches' brooms, early leaves reddening, and poor taste and small size fruits, which cause important qualitative and quantitative reduction of the production. The transmission of ' $\mathrm{Ca}$. Phytoplasma mali' by insect vectors in Italy and Germany is associated with two different Cacopsylla species: Cacopsylla picta (Förster), the main vector in Germany and Northeast Italy [19-21] and Cacopsylla melanoneura (Förster), which is the main vector in Northwest Italy [22-24].

In this article the validation of a Real-time PCR protocol was established using the species-specific primer pair rpAP15f-mod/rpAP15r3 previously designed in the variable region of the ribosomal protein (rp) gene $r p I V(r p l 22)$ of ' $C a$. Phytoplasma mali' [25], especially for the detection and quantification of this phytoplasma in insects. The choice of this gene for ' $\mathrm{Ca}$. Phytoplasma mali' detection is due to its major variability than the 16S rDNA gene [26], which has been already used 
as a target for the specific detection and quantification of ' $\mathrm{Ca}$. Phytoplasma prunorum' in its natural hosts [27]. The method presented in this paper is implemented compared to the method published in the abstract [25] due to the use of EvaGreen ${ }^{\circledR}$ dye, whose advantages have been stated above in comparison to $\mathrm{SYBR}^{\circledR}$ Green $\mathrm{I}$, and the utilization of a ready-to-use $2 \mathrm{x}$ supermix which makes the experiments faster and less prone to errors. Finally, the present work provided all the results needed to demonstrate that this Real-time PCR protocol can be used for a specific, sensitive and reliable quantification of ' $\mathrm{Ca}$. Phytoplasma mali' in insect.

\section{MATERIALS AND METHODS}

\subsection{Phytoplasma sources and DNA extraction}

Field collected ' $C a$. Phytoplasma mali'-infected C. melanoneura were used in this study. DNAs from overwintered adults were tested. To validate the Real-time PCR protocol, other field collected insects were tested: 'Ca. Phytoplasma prunorum'-infected Cacopsylla pruni (Scopoli), 'Ca. Phytoplasma pyri'-infected Cacopsylla pyri L., Flavescence Dorée (FD) phytoplasma (16SrV-C)infected Scaphoideus titanus Ball and 'Ca. Phytoplasma phoenicium' (16SrIX-D, the causal agent of almond witches' brooms, AlmWB)-infected insects [28].

Total DNA was extracted from single insects using a CTAB-based protocol developed for leafhoppers [29] and already applied to psyllids [22]. The DNA extracted from each insect was resuspended in 1X TE Buffer, quantified by using NanoDrop Spectrofotometer (Thermo Fisher Scientific, Wilmington, DE, USA), and stored at $-20^{\circ} \mathrm{C}$ until use.

\subsection{Phytoplasma detection by nested-PCR and RFLP analyses}

The presence of phytoplasma in the insects was previously assayed by conventional nested-PCR using 16S rDNA universal and group specific primers followed by RFLP analyses.

In particular for the characterization of the $16 \mathrm{SrX}$-group phytoplasmas, a direct PCR using the phytoplasma universal primer pair P1/P7 [30,31] was first carried out. Then, a 1:40 dilution of each amplicon was used as template in the following nested-PCR, by using the group-specific primer pair fO1/rO1 [15]. Direct PCR was performed in $20 \mu 1$ reaction volume containing $1 \mu 1$ of insect DNA, while nested PCR was performed in $40 \mu \mathrm{l}$ reaction volume containing $2 \mu 1$ of diluted P1/P7 amplicon. In order to discriminate ' $\mathrm{Ca}$. Phytoplasma mali', ' $\mathrm{Ca}$. Phytoplasma prunorum' and ' $\mathrm{Ca}$. Phytoplasma pyri' a RFLP analysis of fO1/rO1 PCR products was performed with the endonucleases $S s p \mathrm{I}$ and $R s a \mathrm{I}$. Three microliters of the amplicons were digested with $3 \mathrm{U}$ of $S s p \mathrm{I}$ for $4.5 \mathrm{~h}$ at $37^{\circ} \mathrm{C}$ and with $5 \mathrm{U}$ of $R s a \mathrm{I}$ at $37^{\circ} \mathrm{C}$ overnight, respectively. 


\subsection{Establishment of a Real-time PCR procedure for the specific detection of 'Ca.}

\section{Phytoplasma mali' in C. melanoneura}

A Real-time PCR protocol was set up using samples infected with ' $\mathrm{Ca}$. Phytoplasma mali' as well as with other phytoplasmas of different groups and sub-groups (PD, ESFY, FD and AlmWB phytoplasmas) as controls. For the detection and quantification of ' $\mathrm{Ca}$. Phytoplasma mali' two Real-time PCRs were used. In the first one rpAP15f-mod/rpAP15r3 primer pair (5'TGCTGAAGCTAATTTGGC-3' / 5' -CCCATGAATATTAACCTCCT-3') [25] which amplify a specific fragment of $238 \mathrm{bp}$ located in the variable region of the ribosomal protein (rp) $\mathrm{rplV}$ gene (rpl22), was chosen. To be able to normalize the data and quantify the phytoplasma titre, a second Real-time PCR was set up using a primer pair which has a portion of the 18S rDNA gene of the insect DNA as target. The primers MqFw/MqRv (5'-AACGGCTACCACATCCAAGG-3'/ 5'GCCTCGGATGAGTCCCG-3') [32], which amplify a 98 bp region of $18 \mathrm{Sr}$ DNA, were used. They were previously designed on the consensus sequence obtained from the alignment of Euscelidius variegatus (Kirschbaum) (EVU15148), Philaenus spumarius L. (PSU06480), and Trioza eugeniae Froggatt (TEU06482) 18S rDNA sequences [32]. At the beginning of the assay, the efficiency of $\mathrm{MqFw} / \mathrm{MqRv}$ primer pair for the amplification of $18 \mathrm{~S}$ rDNA in C. melanoneura was evaluated. The Real-time PCR reactions were carried out in a $25 \mu 1$ volume, which was composed by the following components: $12.5 \mu \mathrm{l}$ of SsoFast ${ }^{\mathrm{TM}}$ EvaGreen $^{\circledR}$ Supermix 2x (Bio-Rad, CA) (containing dNTPs, Sso7d fusion polymerase, $\mathrm{MgCl}_{2}$, EvaGreen ${ }^{\circledR}$ dye, and stabilizers), $2.5 \mu$ of each primer $(3 \mu \mathrm{M})$, $6.5 \mu 1$ of Milli-Q water and $1 \mu 1$ of DNA templates at different concentrations (range from 19.91 to $392.31 \mathrm{ng} / \mu \mathrm{l})$ (Table 2).

For each reaction, 96-wells plates were used and the standards and samples were run in triplicates. An additional sample, containing water instead of DNA, was added to each plate in triplicate as DNA-free negative control. The reaction was conducted in a DNA Engine Opticon ${ }^{\mathrm{TM}}$ System (Bio$\mathrm{Rad}, \mathrm{CA})$. For the amplification of ' $\mathrm{Ca}$. Phytoplasma mali' the following thermal conditions were used: incubation step at $95^{\circ} \mathrm{C}$ for $2 \mathrm{~min}, 40$ cycles of amplification at $94^{\circ} \mathrm{C}$ for $15 \mathrm{~s}, 56^{\circ} \mathrm{C}$ for $15 \mathrm{~s}$, $72^{\circ} \mathrm{C}$ for $20 \mathrm{~s}$, and a final extension step at $72^{\circ} \mathrm{C}$ for $8 \mathrm{~min}$. On the contrary, for the quantification of $18 \mathrm{~S}$ rDNA, the following thermal protocol was used: incubation step at $94^{\circ} \mathrm{C}$ for $3 \mathrm{~min}$, 37 cycles of amplification at $94^{\circ} \mathrm{C}$ for $45 \mathrm{~s}, 65^{\circ} \mathrm{C}$ for $1 \mathrm{~min}$. Two melting curve profiles, the first ramp from $65^{\circ} \mathrm{C}$ to $95^{\circ} \mathrm{C}$ at $0.2^{\circ} \mathrm{C} / \mathrm{sec}$ and the second one from $65^{\circ}$ to $94^{\circ} \mathrm{C}$ at $0.5^{\circ} \mathrm{C} / \mathrm{s}$ were run. Both absolute quantifications, expressed as genome units (GU) for ' $\mathrm{Ca}$. Phytoplasma mali' and pg for insect $18 \mathrm{~S}$ rDNA, were achieved plotting the samples $\mathrm{C}_{\mathrm{T}}$ against the standard curves prepared from serial dilutions of plasmids containing rplV-rpsC and a portion of $18 \mathrm{~S}$ rDNA gene, respectively. 
Analyses of melting curves generated from each assay were also carried out for the detection of possible non-specific products. Furthermore, in order to validate the method, accuracy, repeatability and reproducibility of the assay were assessed.

\subsection{Establishment of calibration curves for the quantification of phytoplasma and insect} DNAFor quantification of ' $C a$. Phytoplasma mali' in $C$. melanoneura a standard curve was established by diluting plasmid pGEM $^{\circledR}$ Easy Vector (Promega, WI, USA) containing rp genes (rplV-rpsC, EF193366) of AP15 phytoplasma (here called AP-15 clone) [25]. Furthermore, for quantification of insect $18 \mathrm{~S}$ rDNA another standard curve using the plasmid pGEM $^{\circledR}$ Easy Vector (Promega, WI, USA) containing the $98 \mathrm{bp}$ fragment of the insect 18S rDNA sequence (here called Mq clone) [32] was established. Both plasmids were first quantified by using NanoDrop Spectrofotometer and then used to prepare 1:10 serial dilutions in Milli-Q water.

For quantification of ' $\mathrm{Ca}$. Phytoplasma mali' the concentration ng/ $\mu 1$ of AP-15 clone was converted to copy number of the insert, rp genes, (equal to GU of phytoplasmas), therefore the dilutions ranged from $1.15^{*} 10^{9}$ to $115 \mathrm{GU} / \mu 1$.

On the other hand, the quantification of the whole $C$. melanoneura $18 \mathrm{~S}$ rDNA was estimated starting from the quantity of $18 \mathrm{~S}$ rDNA inserted fragment. This estimation was carried out considering that $18 \mathrm{~S}$ rDNA of Sternorrhyncha (which includes psyllids, whiteflies, aphids and scales) has a long length ( $\sim 2200$ to $\sim 2500 \mathrm{bp})$ due to the presence of internal expansions [33] and that the only complete $18 \mathrm{~S}$ rDNA sequence for a psyllid is the one from $T$. eugeniae (GenBank accession $\mathrm{n}^{\circ} \mathrm{U} 06482 ; 2199 \mathrm{bp}$ ), which was also one of the species used for the MqFw/MqRv primer pair design [32]. Since the inserted fragment amplified by the MqF/MqR primer pair (98bp) is about $1 / 20$ of the whole $18 \mathrm{~S}$ rDNA of $T$. eugeniae, we estimated the amount of the whole $18 \mathrm{~S}$ rDNA of C.melanoneura multiplying by 20 the quantity assessed for the fragment; therefore the Mq clone dilutions ranged from $4.47 * 10^{3}$ to $4.47 * 10^{-4} \mathrm{pg}$ of $18 \mathrm{~S} \mathrm{rDNA} / \mu 1$.

The standard curves were constructed by the interpolation of the $\log 10$ of the copy number of each standard plotted along the $\mathrm{x}$-axis with their respective $\mathrm{Ct}$ values along the $\mathrm{y}$-axis.

' $C a$. Phytoplasma mali' titre in insects was expressed as genome units (GU) of phytoplasma per picogram (pg) of individual insect 18S rDNA.

2.5 Sensitivity evaluation of the Real-time PCR approach for the detection of 'Ca. Phytoplasma mali' 
In order to test the sensitivity of the Real-time PCR method, a comparison with the conventional PCR approach for the detection of ' $\mathrm{Ca}$. Phytoplasma mali' was carried out. In the specific, 10-fold serial dilutions (from $10^{9}$ to 1 ) of total DNA extracted from a ' $\mathrm{Ca}$. Phytoplasma mali'-infected insect were prepared in Milli-Q water. Dilutions were tested by direct PCR with the universal primer pair P1/P7 followed by nested-PCR using the AP-group specific primer pair $\mathrm{fO} 1 / \mathrm{rO} 1$. Five $\mu 1$ of each $\mathrm{fO} 1 / \mathrm{rO} 1$ amplicon were run on a $1 \%$ electrophoresis gel, stained in Etidium Bromide and visualized under UV light. Real time quantitative PCR with the primer pair rpAP15f-mod/rpAP15r3 was also carried out for the simultaneous detection and quantification of ' $\mathrm{Ca}$. Phytoplasma mali'. Standards and samples were also run in triplicates.

\section{RESULTS}

\subsection{Specificity of the Real-time PCR protocol}

On a total of 61 samples included in the assay only sample DNA of ' $\mathrm{Ca}$. Phytoplasma mali' infected insects and the AP-15 clone were successfully amplified using the primer pair rpAP15Fmod/rpAP15r3 (Tab.1). No amplification curves were observed with C. pruni and C. pyri samples infected with 'Ca. Phytoplasma prunorum' and ' $C a$. Phytoplasma pyri', respectively. On the contrary, some of the examined $S$. titanus specimens infected with FD phytoplasma showed amplification curve at $\mathrm{C}_{\mathrm{T}} 13.72( \pm 0.5)$, while all the other FD phytoplasma samples did not show any amplification curves. The analysis of the dissociation (melting) curve revealed a single peak at $75.5^{\circ} \mathrm{C}( \pm 0.26)$ for all the ' $\mathrm{Ca}$. Phytoplasma mali'-infected samples and for the AP-15 clone, while no peaks were observed for the other phytoplasmas (Fig. 1), including FD.

\subsection{Method validation, evaluation of the efficiency of the assay and quantification of 'Ca.}

\section{Phytoplasma mali' titre}

Before sample quantification, the efficiency of standard curve for $18 \mathrm{~S}$ rDNA gene in $C$. melanoneura was evaluated. A mean slope of $-3.474( \pm 0.05)$ and a $\mathrm{R}^{2}>0.999$ demonstrated an efficiency of 94\% (Fig 2 b). For ' $\mathrm{Ca}$. Phytoplasma mali' quantification, standard curves resulted in a mean slope of $-3.345( \pm 0.08)$ and a correlation coefficient $\left(\mathrm{R}^{2}\right)>0.998$, which demonstrated an efficiency of $99 \%$. Phytoplasma titre was quantified in all C. melanoneura overwintered adults included in this study. Samples with $\mathrm{C}_{\mathrm{T}}$ higher than the one of the last standard (standard $10^{-8}$ ), which corresponds to $\mathrm{C}_{\mathrm{T}} 30$, were considered negative. Results of the quantification of phytoplasma titre are illustrated in Tab. 2. In the specific, infection level of $C$. melanoneura overwintered adults showed an interval of phytoplasma concentration from $5.94 * 10^{2}$ to $2.51 * 10^{4} \mathrm{GU} / \mathrm{pg}$ of insect $18 \mathrm{~S}$ rDNA. 
Accuracy of the assays were evaluated by running three replicates for each sample and standard dilution in each plate. Intra-variance (intra-assay repeatability) was calculated by considering three replicates of the same sample in the same run, while inter-variance (inter-assay reproducibility) was evaluated by running the same sample in two different runs in different days. For phytoplasma qPCR assay, the tests revealed an intra-variance with an average coefficient of variation $(\mathrm{CV})$ equal to $5.26 \%$, and an inter-assay variance of $6.79 \%$ (Tab.3a and 4a). Instead, for insect qPCR assay, an average $\mathrm{CV}$ equal to $5.89 \%$ for the reproducibility was revealed, while a mean $\mathrm{CV}$ of $5.03 \%$ was tested for the repeatability assay (Tab. $3 b$ and $4 b$ ).

\subsection{Sensitivity comparison between Real-time PCR and conventional approach for the} detection of 'Ca. Phytoplasma mali'

Figure 3 shows the results obtained with the two approaches. For conventional PCR approach both direct and nested PCR are shown in order to better visualize the differences in band intensity of the different sample dilutions (Fig. 3). For Real-time PCR method, $\mathrm{C}_{\mathrm{T}}$ averages and quantification for each sample dilution are shown. Same level of sensitivity in APP detection was observed in both conventional and Real-time PCR. The last dilution detected by both methods was the $10^{5}$-fold one corresponding to the $C_{T} 31.62$ and to the quantity of $38 \mathrm{GU} / \mu 1$ in Real-time PCR.

\section{DISCUSSION}

Several Real-time PCR approaches have been developed for the detection and quantification of $16 \mathrm{SrX}$ phytoplasma group and ' $\mathrm{Ca}$. Phytoplasma mali' using different labeling systems and different target sequences. These works are based on the use of SYBR Green technology for quantification of $16 \mathrm{SrX}$ phytoplasma group in plants [9] and specific ' $\mathrm{Ca}$. Phytoplasma mali' quantification in host plants and vectors [8, 20]. On the other hand, Baric \& Dalla-Via [34] and Aldaghi [35] developed and used, respectively, a TaqMan Minor Groove Binding (MGB) probe system for the specific detection of ' $\mathrm{Ca}$. Phytoplasma mali' in plant material, similarly Nikolić [36] used the same technology for the specific detection and discrimination of ' $\mathrm{Ca}$. Phytoplasma mali', ' $\mathrm{Ca}$. Phytoplasma prunorum' and ' $\mathrm{Ca}$. Phytoplasma pyri'. In this work a Real-time PCR protocol, based on the use of EvaGreen ${ }^{\circledR}$ intercalating dye and a primer pair previously designed on the ribosomal protein $r p l V$ gene, has been developed for the specific detection and quantification of ' $C a$. Phytoplasma mali' in insects. Since its commercialization, the use of EvaGreen ${ }^{\circledR}$ dye has been greatly increasing. In fact, its application varies from quantitative PCR, DNA conformation detection, double-stranded DNA tracing and quantification in capillary electrophoresis to melting 
analysis on a Lab-on-Chip, and Real-time isothermal DNA amplifications. Even though this chemistry detection system is not as specific as a TaqMan ${ }^{\circledR}$ probes or Molecular Beacons (based on the highly specific bind to target sequence), it results less expensive and easy to use because it only requires the design and synthesis of two PCR primers, which decreases assay setup and costs. Furthermore, EvaGreen technology also shows many advantages comparing with the most used intercalating dye $\mathrm{SYBR}^{\circledR}$ Green I. In 2007 Mao et al. [37], who developed EvaGreen ${ }^{\circledR}$ dye, compared its physicochemical properties to $\mathrm{SYBR}^{\circledR}$ Green I characteristics. In this study they demonstrated for EvaGreen ${ }^{\circledR}$ a higher reproducibility, a less PCR inhibition effect, weak binding for short dsDNA fragments (which reflects the low tendency to promote not specific amplification), as well as, higher and narrowed melting curves compared with SYBR ${ }^{\circledR}$ Green I, also demonstrated by Eischeid [13]. So, findings from this work and results from Mao [37] and Eischeid [13] demonstrated the efficiency of EvaGreen chemistry and its application in qPCR and post-PCR DNA melting curve analysis, which is required when nonspecific binding dye is used in a qPCR assay. In fact here, from the specificity test, a clear dissociation peak at $75^{\circ} \mathrm{C}$ for all ' $\mathrm{Ca}$. Phytoplasma mali' samples was observed, while the phytoplasmas used as controls showed no peaks, indicating that the fluorescence signals were caused by amplification artifacts. In fact, an example of the importance of melting curve analysis was demonstrated from some of the FD phytoplasmas DNA, which showed amplification curves at $C_{T} 13.72( \pm 0.5)$. However, from an accurate melting curve analysis, no peaks were observed for all of them, which indicate fluorescence artifacts.

Furthermore, the results also validated the specificity of the rpAP15f-mod/rpAP15r3 primer pair. The gene $r p l V$ ( $r p l 22)$ was chosen as amplification target [26,25] for the higher variability of ribosomal protein genes compared to $16 \mathrm{~S}$ rDNA, which substantially increase the resolving power of differentiating and classifying distinct phytoplasma strains within a given $16 \mathrm{Sr}$ group [26,38,39].

In our work rpAP15f-mod/rpAP15r3 primer pair, obtained from the multiple alignment of $r p l V$ gene of several phytoplasma strains [25], allows not only the discrimination of phytoplasmas belonging to different groups, but also of the subgroups within the $16 \mathrm{SrX}$ group (which also includes ' $C a$. Phytoplasma prunorum' and 'Ca. Phytoplasma pyri').

As for phytoplasma detection, no difference in terms of sensitivity was detected comparing the Real-time PCR assay with classic APP detection approach, which includes a direct PCR with universal primers P1/P7 [31], a nested-PCR with the group-specific primer pair fO1/rO1 [15] followed by a RFLP analysis for the ' $\mathrm{Ca}$. Phytoplasma mali' discrimination within the 16SX group [15]. These data indicates that both the approaches are sensitive for APP detection. However, Realtime PCR assay has more advantages, such as the rapidity of the assay, the quantification of 
phytoplasma titre as well as less chances of false-positive results (due to cross-contaminations between direct and nested-PCR). In fact, Real-time PCR approach is a faster detection system than nested-PCR since it avoids post-PCR amplification processes, as gel electrophoresis to verify sequences amplification, and RFLP analysis for the confirmation of ' $\mathrm{Ca}$. Phytoplasma mali' presence.

In order to quantify ' $\mathrm{Ca}$. Phytoplasma mali' titre in insects, two absolute Real-time PCR were carried out for each sample: one for the quantification of the phytoplasma cells and the other for the quantification of C. melanoneura $18 \mathrm{~S}$ rDNA. In particular, this second assay is necessary to avoid the fluctuations in yields during DNA extractions [32], resulting in a relative quantification of the phytoplasma in relation to each insect $18 \mathrm{~S}$ rDNA. MqFw/MqRv primer pair, designed on the consensus sequence obtained from the alignment of E. variegatus, P. spumarius, and T. eugeniae 18S rDNA sequences [32] was used, and the efficiency was evaluated at the beginning of the assay. A value of $94 \%$ (for $18 \mathrm{~S}$ rDNA) and 99\% (for $r p l V$ gene), achieved from the mean of each run for both assays, were obtained, so indicating a good amplification efficiency. Besides that, it has been also demonstrated its repeatability and reproducibility. Referring to Bustin [40] in our work the variance of phytoplasma $\mathrm{GU}$ and pg of insect $18 \mathrm{~S}$ rDNA were taken into account, because $\mathrm{C}_{\mathrm{T}}$ values generated from different runs are subjected to inherent inter-run variation [41]. Both tests evaluated the variance expressed as coefficient of variation (CV\%) of GU and pg, which were calculated between replicates of the same sample within the same assay (intra-variance or repeatability) and between different runs for the same sample (inter-assay or reproducibility). In the specific, coefficient of variation of less than 9 and 10\% (reproducibility test) and less than 13\% and $5.88 \%$ (repeatability test) for phytoplasma and insect qPCR assay were obtained, respectively. Therefore, these tests demonstrated that the method is reliable and also robust in terms of repeatability and reproducibility.

For the quantifications, considering that the ribosomal protein gene $r p l V$ belongs to the $S 10-s p c-\alpha$ operon, which is present in a single-copy in the genome of phytoplasmas and other Mollicutes $[42,43]$, the final phytoplasma concentrations were calculated as the ratio of APP GU per pg insect $18 \mathrm{~S}$ rDNA.

Results from the quantification assay, showed a range of phytoplasma infection level from $5.94 * 10^{2}$ to $2.51 * 10^{4} \mathrm{GU} / \mathrm{pg}$ insect $18 \mathrm{~S}$ rDNA. This variability in phytoplasma titre within the examined group (overwintered adults) could be explained by the fact that each insect can have different acquisition efficiency, and moreover, some of them can have acquired the APP during the previous 
season and possibly recharged it after the overwintering period and others can have acquired the phytoplasma only after the overwintering period.

This implemented Real-time PCR protocol has been demonstrated being a valid and efficient approach for the quantification of ' $\mathrm{Ca}$. Phytoplasma mali' titre in insects. The possibility to study the trend of phytoplasma titre in the insect will allow a deepen investigation on the epidemiology of the disease. Furthermore, it can help to better understand the biology of the pathogen, as well as the interaction between phytoplasma and insect vector. Finally, it can also be useful for developing better vector control strategies.

\section{Acknowledgements}

This work was financially supported by Regione Autonoma Valle d'Aosta with a $\mathrm{PhD}$ grant established in the memory of the brothers "Ugo and Liliana Brivio" (Testamentary bequest by Prof. Liliana Brivio for fellowships and grants).

\section{References}

[1] Bertaccini A. Phytoplasmas: diversity, taxonomy, and epidemiology. Front Biosci 2007;12:67389.

[2] Lee I-M, Davis RE, Gundersen-Rindal DE. Phytoplasma: Phytopathogenic Mollicutes. Annu Rev Microbiol 2000;54:221-55.

[3] Bertaccini A, Duduk B. Phytoplasma and phytoplasma diseases: a review of recent research. Phytopathol Mediterr 2009;48:355-78.

[4] Firrao G, Garcia-Chapa M, Marzachì C. Phytoplasmas: genetics, diagnostics and relationships with the plant and insect host. Front Biosci 2007;12:1353-75.

[5] Anderson TP, Werno AM, Beynon KA, Murdoch DR. Failure to genotype herpes simplex virus by real-time PCR assay and melting curve analysis due to sequence variation within probe binding sites. J Clin Microbiol 2003;41(5):2135-37.

[6] Papin JF, Vahrson W, Dittmer D. SYBR Green-based real-time quantitative PCR assay for detection of West Nile virus circumvents false-negative results due to strain variability. J Clin Microbiol 2004;42(4):1511-18.

[7] Galetto L, Marzachì C. Real-time PCR diagnosis and quantification of phytoplasmas. In: Weintraub PG, Jones P, editors. Phytoplasma Genomes, Plant Hosts and Vectors. CABI Publishers, USA;2010, p.1-19.

[8] Galetto L, Bosco D, Marzachì C. Universal and group-specific real-time PCR diagnosis of flavescence dorée $(16 \mathrm{Sr}-\mathrm{V})$, bois noir $(16 \mathrm{Sr}-\mathrm{XII})$ and apple proliferation (16Sr-X) 
phytoplasmas from field-collected plant hosts and insect vectors. Ann Appl Biol 2005;147:191201.

[9] Torres E, Bertolini E, Cambria M, Monton C, Martin MP. Real- time PCR for simultaneous and quantitative detection of quarantine phytoplasmas from apple proliferation (16SrX) group. Mol Cell Probe 2005;19:334-40.

[10] Ririe KM, Rasmussen RP, Wittwer CT. Product differentiation by analysis of DNA melting curves during the polymerase chain reaction. Anal Biochem 1997;245:154-60.

[11] Nath K, Sarosy JW, Hahn J, Di Como CJ. Effects of ethidium bromide and SYBR ${ }^{\circledR}$ Green I on different polymerase chain reaction systems. J Biochem Bioph Meth 2000;42:15-29.

[12] Giglio S, Monis PT, Saint CP. Demonstration of preferential binding of SYBR Green I to specific DNA fragments in real-time multiplex PCR. Nucleic Acids Res 2003;31:e106

[13] Eischeid AC. SYTO dyes and EvaGreen outperform SYBR Green in real-time PCR. BMC Res Notes $2011 ; 4: 263$

[14] Jarausch W, Saillard C, Helliot B, Garnier M and Dosba F. Genetic variability of apple proliferation phytoplasmas as determined by PCR-RFLP and sequencing analysis of a nonribosomal fragment. Mol Cell Probes 2000;14:17-24.

[15] Lorenz K H, Schneider B, Ahrens U, Seemüller E. Detection of the Apple Proliferation and Pear Decline Phytoplasmas by PCR amplification of ribosomal and non ribosomal DNA. Phytopathology 1995;85:771-76.

[16] Lee I-M, Bertaccini A, Vibio M, Gundersen DE. Detection of multiple phytoplasmas in perennial fruit trees with decline symptoms in Italy. Phytopathology 1995;85:728-35.

[17] Kison H, Kirkpatrick BC, Seemüller E. Genetic comparison of the peach yellow leaf roll agent with European fruit tree phytoplasmas of the apple proliferation group. Plant Pathol 1997;46: 538-44.

[18] Danet JL, Balakishiyeva G, Cimerman A, Sauvion N, Marie-Jeanne V, Labonne G, et al. Multilocus sequence analysis reveals the genetic diversity of European fruit tree phytoplasmas and the existence of inter species recombination. Microbiology 2010;157:438-50.

[19] Frisinghelli C, Delaiti L, Grando MS, Forti D, Vindimian ME. Cacopsylla costalis (Flor, 1861), as a vector of apple proliferation in Trentino. J Phytopathol 2000;148:425-31.

[20] Jarausch B, Schwind N, Jarausch W, Krczal G. Overwintering adults and springtime generation of Cacopsylla picta (synonym C. costalis) can transmit apple proliferation phytoplasmas. Acta Hortic 2004;657:409-13. 
[21] Jarausch B, Schwind N, Jarausch W, Krczal G, Dickler E, Seemüller E. First report of Cacopsylla picta as a vector of apple proliferation phytoplasma in Germany. Plant Dis 2003;87:101.

[22] Tedeschi R, Bosco D, Alma A. Population dynamics of Cacopsylla melanoneura (Homoptera: Psyllidae), a vector of apple proliferation in northwestern Italy. J Econ Entomol 2002;95:544-51.

[23] Tedeschi R, Alma A. Transmission of apple proliferation phytoplasma by Cacopsylla melanoneura (Homoptera: Psyllidae). J Econ Entomol 2004;97(1):8-13.

[24] Tedeschi R, Baldessari M, Mazzoni V, Trona F, Angeli G. Population dynamics of Cacopsylla melanoneura (Hemiptera: Psyllidae) in northeast Italy and its role in the apple proliferation epidemiology in apple orchards. J Econ Entomol 2012;105(2):322-8.

[25] Martini M, Ermacora P, Loi N, Carraro L, Osler R. Specific detection of 'Candidatus Phytoplasma mali' by a new real-time PCR method based on ribosomal protein gene. COST Action FA0807, Current Status and perspective of phytoplasma disease research and management, Sitges, Spain February 1st and 2nd 2010, abstract book: 23.

[26] Martini M, I-M, Bottner, KD, Zhao Y, Botti S, Bertaccini A, et al. Ribosomal protein genebased phylogeny for finer differentiation and classification of phytoplasmas. Int J Syst Evol Micr 2007;57:2037-51.

[27] Martini M, Loi N, Ermacora P, Carraro L, Pastore M. A real-time PCR method for detection and quantification of 'Candidatus Phytoplasma prunorum' in its natural hosts. B Insectol 2007; $60(2): 251-2$.

[28] Molino Lova M, Quaglino F, Abou-Jawadah Y, Choueiri E, Sobh H, Casati P, et al. Identification of new 16SrIX subgroups, -F and -G, among 'Candidatus Phytoplasma phoenicium' strains infecting almond, peach and nectarine in Lebanon. Phytopathol Mediterr 2011; 50: 273-82.

[29] Marzachì C, Veratti F, Bosco D. Direct PCR detection of phytoplasmas in experimentally infected insects. Ann Appl Biol 1998;133:45-54.

[30] Deng S, Hiruki C. Amplification of 16S rRNA genes from culturable and unculturable mollicutes. J Microbiol Meth 1991;14:53-61.

[31] Schneider B, Seemüller E, Smart CD, Kirkpatrick BC. Phylogenetic Classification of Plant Pathogenic Mycoplasmalike Organisms or Phytoplasmas. In: Razin S, Tully JG, editors. Molecular and Diagnostic Procedures in Mycoplasmology, San Diego: Academic Pres; 1995,p. 369-80. 
[32] Marzachì M, Bosco D. Relative Quantification of Chrysanthemum Yellows (16Sr 1) Phytoplasma in Its Plant and Insect Host Using Real-Time Polymerase Chain Reaction. Mol Biotechnol 2005;30:117-27.

[33] Campbell BC, Steffen-Campbell JD, Gill RJ. Evolutionary origin of whiteflies (Hemiptera: Sternorrhyncha: Aleyrodidae) inferred from 18S rDNA sequences. Insect Mol Biol 1994;3: 7388.

[34] Baric S, Dalla-Via J. A new approach to apple proliferation detection: a highly sensitive realtime PCR assay. J Microbiol Meth 2004;57:135-45.

[35] Aldaghi M, Massart S, Roussel S, Jijakli MH. Development of a new probe for specific and sensitive detection of 'Candidatus Phytoplasma mali' in inoculated apple trees. Ann App Biol 2007;151:251-58.

[36] Nikolić P, Mehle N, Gruden K, Ravnikar M, Dermastia M. A panel of real-time PCR assays for specific detection of three phytoplasmas from the apple proliferation group. Mol Cell Probe 2010;24:303-9.

[37] Mao F, Leung W-Y, Xin X. Characterization of EvaGreen and the implication of its physicochemical properties for qPCR applications. BMC Biotechnol 2007;7:76.

[38] Martini M, Ermacora P, Falgin-ella L, Loi N, Carraro L. Molecular differentiation of 'Candidatus Phytoplasma mali' and its spreading in Friuli Venezia Giulia region (north-east Italy). Acta Hortic 2008;781:395-402.

[39] Martini M, Lee I-M. PCR and RFLP analyses based on the ribosomal protein operon. Meth Mol Biol 2013;938:173-88

[40] Bustin SA, Benes V, Garson JA, Hellemans J, Huggett J, Kubista M, et al. The MIQE guidelines: minimum information for publication of quantitative Real-Time PCR experiments. Clin Chem 2009;55(4):611-22.

[41] Hellemans J, Mortier G, De Paepe A, Speleman F, Vandesompele J. qBase relative quantification framework and software for management and automated analysis of real-time quantitative PCR data. Genome Biol 2007;8:R19.

[42] Lim PO, Sears BB. Evolutionary relationship of a plant-pathogenic mycoplasmalike organism and Acholeplasma laidlawii deduced from two ribosomal protein gene sequences. J Bacteriol 1992;174:2606-11.

[43] Miyata SI, Furuki KI, Oshima K, Sawayanagi T, Nishigawa H, Kakizawa S, et al. Complete nucleotide sequence of the S10-spc operon of phytoplasma: gene organization and genetic code resemble those of Bacillus subtilis. DNA Cell Biol 2002;21:527-34. 


\section{FIGURE CAPTIONS}

Fig. 1 Melting curve analysis of a) AP-15 clone b) ' $C a$. Phytoplasma mali' c) ' $C a$. Phytoplasma phoenicium' d) FD phytoplasma e) 'Ca. Phytoplasma prunorum' f) 'Ca. Phytoplasma pyri' g) DNA-free control.

Fig. 2 Representative standard curves of 8 -fold dilution series $\left(10^{-8}\right.$ to $\left.10^{-1}\right)$ for quantification of a) 'Ca. Phytoplasma mali' titre, $\mathrm{E}=100 \%$ and b) $C$. melanoneura DNA; E=96\%.

Fig. 3 Sensitivity comparison between conventional PCR and Real time PCR approach for ' $\mathrm{Ca}$. Phytoplasma mali' detection. Dilutions, $\mathrm{C}_{\mathrm{T}}$ and quantification (genome units, $\mathrm{GU}$ ) for each sample dilution from Real-time PCR, direct and nested PCR results; $\mathrm{C}+=$ positive control; $\mathrm{C}$ - = negative control; $\mathrm{M}=1 \mathrm{~kb}-\mathrm{molecular}$ marker; $\mathrm{ND}=$ not detected. 


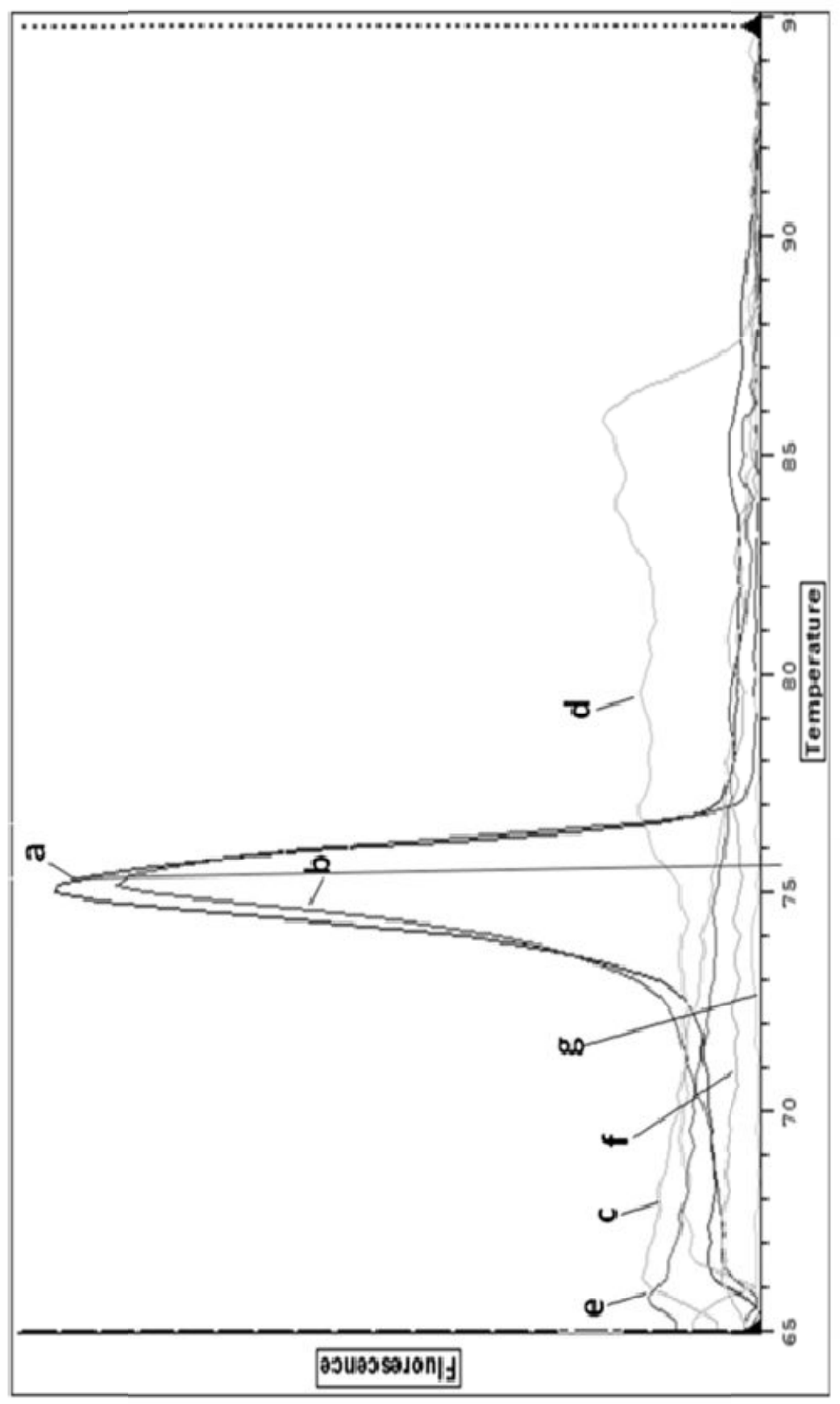

Figure 1 

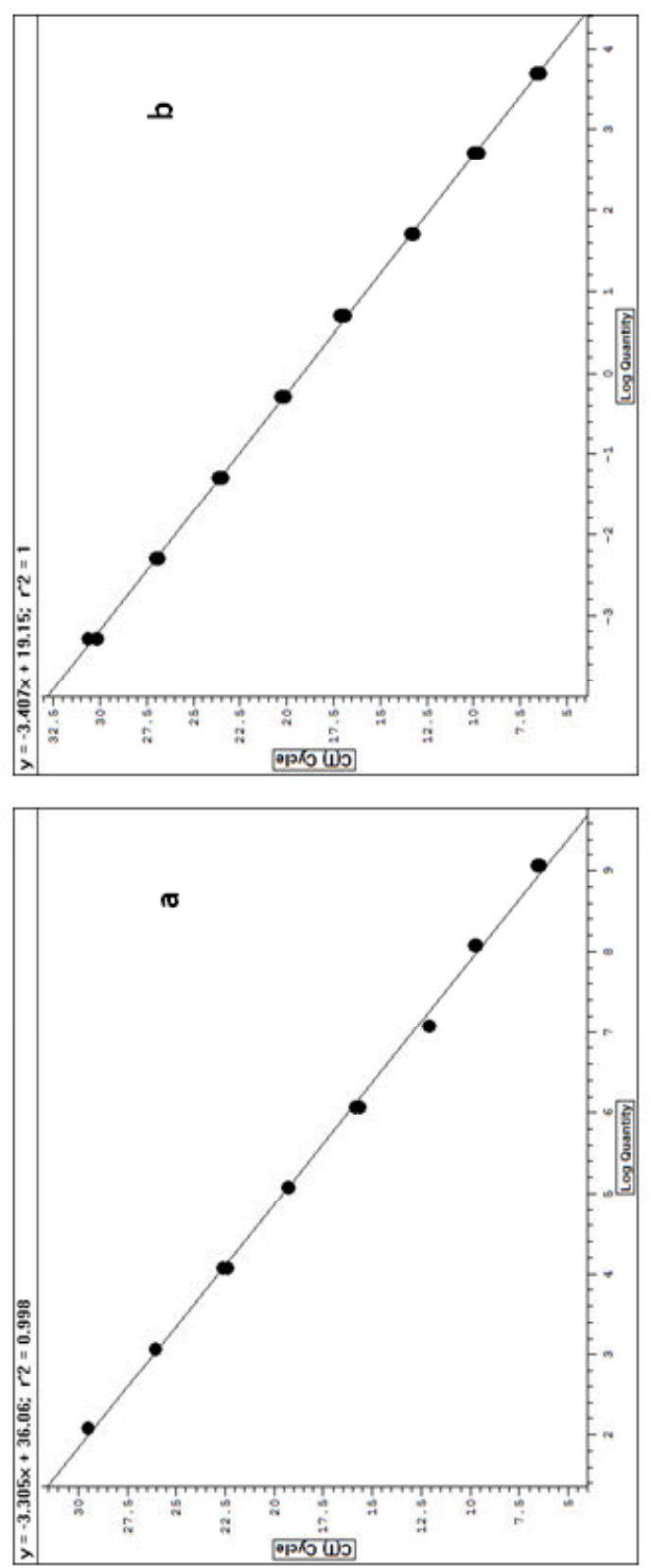

Figure 2 


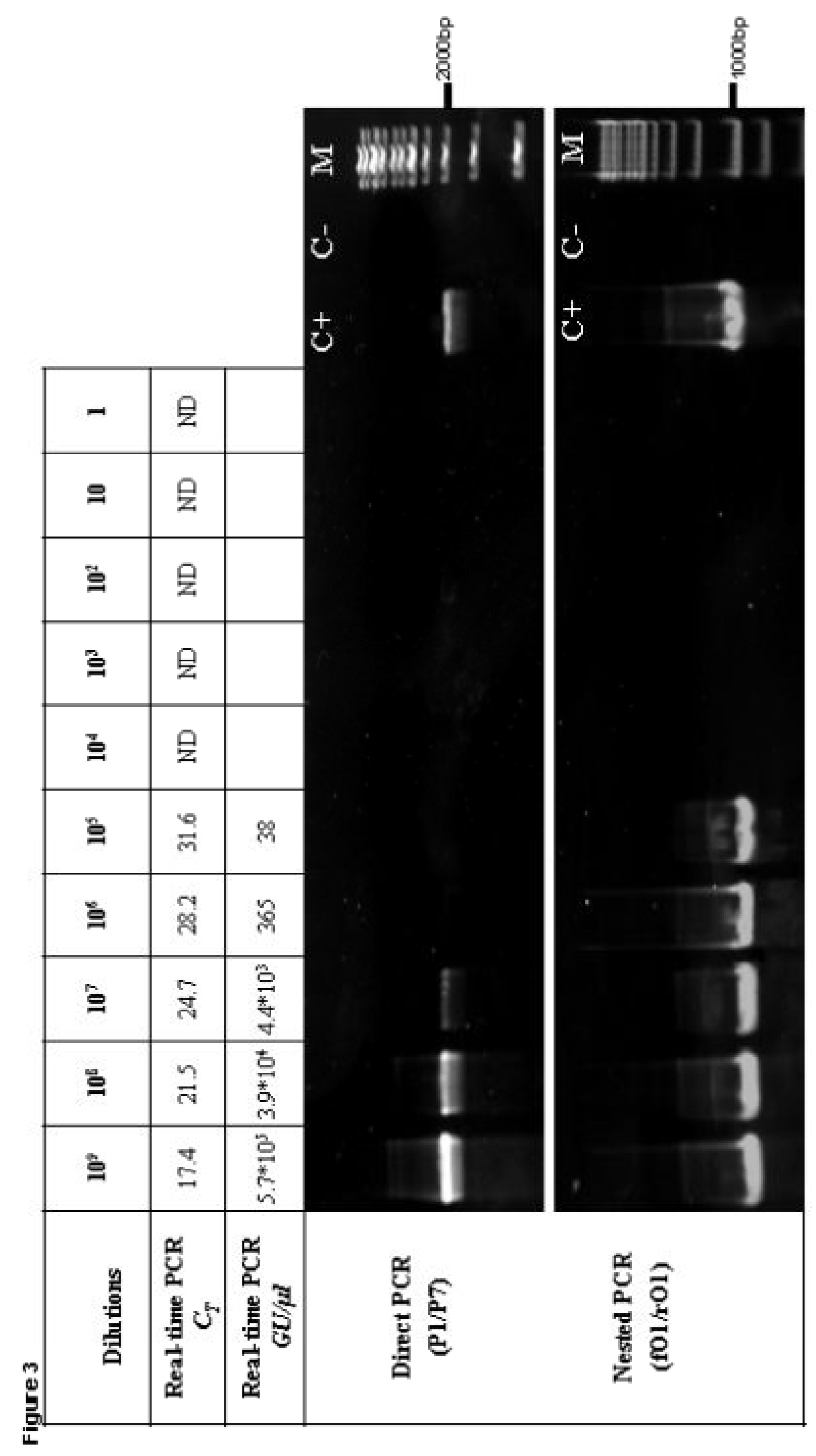




\section{TABLES}

Table 1. Origin and PCR results of samples included in the assay for the validation of method specificity; n.t. $=$ not tested

\begin{tabular}{|c|c|c|c|c|}
\hline \multirow{2}{*}{ Phytoplasmas } & \multirow{2}{*}{$\begin{array}{c}\text { Number } \\
\text { of } \\
\text { samples }\end{array}$} & \multirow[b]{2}{*}{ Origin } & \multicolumn{2}{|c|}{$\begin{array}{c}\text { PCR and RFLP analysis } \\
\text { Results }\end{array}$} \\
\hline & & & $\begin{array}{l}\text { NESTED- } \\
\text { PCR } \\
(\mathrm{fO} 1 / \mathrm{rO} 1)\end{array}$ & $\begin{array}{l}\text { Real-time } \\
\text { PCR } \\
\text { (rpAP15fmod- } \\
\text { rpAP15r3) }\end{array}$ \\
\hline $\begin{array}{l}\text { 'Ca. Phytoplasma mali' } \\
\text { (16SrX-A strain AT-1) }\end{array}$ & 33 & Cacopsylla melanoneura & + & + \\
\hline $\begin{array}{c}\text { 'Ca. Phytoplasma } \\
\text { prunorum' } \\
(16 \mathrm{SrX}-\mathrm{B})\end{array}$ & 7 & Cacopsylla pruni & + & - \\
\hline $\begin{array}{c}\text { 'Ca. Phytoplasma pyri' } \\
(16 \mathrm{SrX}-\mathrm{C})\end{array}$ & 7 & Cacopsylla pyri & + & - \\
\hline $\begin{array}{c}\text { 'Ca. Phytoplasma } \\
\text { phoenicium' } \\
\text { (16SrIX-D) }\end{array}$ & 7 & Insects & n.t. & - \\
\hline $\begin{array}{c}\text { Flavescence Dorée } \\
\text { phytoplasma } \\
(16 \mathrm{SrV}-\mathrm{C})\end{array}$ & 7 & Scaphoideus titanus & n.t. & - \\
\hline
\end{tabular}


Table 2. Real-time PCR quantification results for apple proliferation phytoplasma (APP) in Cacopsylla melanoneura overwintered adults.

\begin{tabular}{|c|c|c|c|c|c|}
\hline \multirow[b]{2}{*}{$\begin{array}{l}\text { DNA } \\
\text { conc. } \\
(n g / \mu l)\end{array}$} & \multicolumn{2}{|c|}{ APP DNA in insect DNA } & \multicolumn{2}{|c|}{ Insect 18S rDNA fragment } & \multirow{2}{*}{$\begin{array}{c}\text { APP GU/ } \\
\text { pg of insect } \\
\text { total 18S } \\
\text { rDNA }\end{array}$} \\
\hline & $\begin{array}{c}\mathbf{C t} \\
(\text { mean } \pm \text { SD) }\end{array}$ & $\begin{array}{c}\text { Quantity } \\
\text { ( GU; mean } \pm \text { SD) }\end{array}$ & $\begin{array}{c}\text { Ct } \\
(\text { mean } \pm \text { SD })\end{array}$ & $\begin{array}{c}\text { Quantity } \\
(\mathrm{pg} ; \text { mean } \pm \text { SD })\end{array}$ & \\
\hline 81.50 & $15.41( \pm 0.10)$ & $2.84 * 10^{6}\left( \pm 1.82 * 10^{5}\right)$ & $15.85( \pm 0.07)$ & $8.91( \pm 0.37)$ & $1.59 * 10^{4}$ \\
\hline 36.13 & $15.07( \pm 0.07)$ & $3.55^{*} 10^{6}\left( \pm 1.54 * 10^{5}\right)$ & $15.68( \pm 0.12)$ & $10( \pm 0.81)$ & $1.78 * 10^{4}$ \\
\hline 44.09 & $15.20( \pm 0.03)$ & $3.26 * 10^{6}\left( \pm 5.94 * 10^{4}\right)$ & $16.33( \pm 0.09)$ & $6.48( \pm 0.38)$ & $2.51 * 10^{4}$ \\
\hline 47.53 & $15.44( \pm 0.07)$ & $2.78 * 10^{6}\left( \pm 1.38 * 10^{5}\right)$ & $16.09( \pm 0.05)$ & $7.6( \pm 0.26)$ & $1.83 * 10^{4}$ \\
\hline 68.04 & $15.25( \pm 0.06)$ & $3.15 * 10^{6}\left( \pm 1.29 * 10^{5}\right)$ & $16.29( \pm 0.05)$ & $6.7( \pm 0.23)$ & $2.35 * 10^{4}$ \\
\hline 42.79 & $15.33( \pm 0.09)$ & $2.98 * 10^{6}\left( \pm 1.85 * 10^{5}\right)$ & $15.79( \pm 0.30)$ & $9.37( \pm 1.75)$ & $1.59 * 10^{4}$ \\
\hline 81.92 & $15.26( \pm 0.14)$ & $3.15^{*} 10^{6}\left( \pm 2.87 * 10^{5}\right)$ & $15.78( \pm 0.06)$ & $8.64( \pm 0.34)$ & $1.82 * 10^{4}$ \\
\hline 52.49 & $17.31( \pm 0.03)$ & $2.47 * 10^{5}\left( \pm 4.21 * 10^{3}\right)$ & $15.16( \pm 0.07)$ & $5.54( \pm 0.26)$ & $2.23 * 10^{3}$ \\
\hline 253.76 & $17.92( \pm 0.23)$ & $1.62 * 10^{5}\left( \pm 2.52 * 10^{4}\right)$ & $13.97( \pm 0.10)$ & $12.48( \pm 0.89)$ & $6.51 * 10^{2}$ \\
\hline 66.27 & $16.54( \pm 0.52)$ & $4.43 * 10^{5}\left( \pm 1.50 * 10^{5}\right)$ & $14.07( \pm 0.06)$ & $11.67( \pm 0.50)$ & $1.90 * 10^{3}$ \\
\hline 71.31 & $17.95( \pm 0.08)$ & $1.58 * 10^{5}\left( \pm 9.15 * 10^{3}\right)$ & $14.35( \pm 0.05)$ & $9.63( \pm 0.30)$ & $8.22 * 10^{2}$ \\
\hline 392.31 & $20.66( \pm 0.24)$ & $7.82 * 10^{4}\left( \pm 1.23 * 10^{4}\right)$ & $15.86( \pm 0.07)$ & $9.18( \pm 0.40)$ & $5.94 * 10^{2}$ \\
\hline 31.13 & $15.12( \pm 0.12)$ & $1.69 * 10^{6}\left( \pm 1.39 * 10^{5}\right)$ & $16.94( \pm 0.05)$ & $4.37( \pm 0.13)$ & $1.93 * 10^{4}$ \\
\hline 37.87 & $17.41( \pm 0.06)$ & $3.36 * 10^{5}\left( \pm 1.44 * 10^{4}\right)$ & $15.22( \pm 0.19)$ & $13.51( \pm 1.64)$ & $1.24 * 10^{3}$ \\
\hline 105.69 & $16.74( \pm 0.04)$ & $5.35 * 10^{5}\left( \pm 1.54 * 10^{4}\right)$ & $15.6( \pm 0.11)$ & $10.51( \pm 0.73)$ & $2.55 * 10^{3}$ \\
\hline 74.87 & $15.41( \pm 0.08)$ & $1.37 * 10^{6}\left( \pm 7.01 * 10^{4}\right)$ & $14.14( \pm 0.08)$ & $27.05( \pm 1.57)$ & $2.53 * 10^{3}$ \\
\hline 28.99 & $15.65( \pm 0.15)$ & $1.16 * 10^{6}\left( \pm 1.18 * 10^{5}\right)$ & $17.33( \pm 0.07)$ & $3.41( \pm 0.15)$ & $1.70 * 10^{4}$ \\
\hline 34.41 & $15.86( \pm 0.10)$ & $1.00 * 10^{6}\left( \pm 6.43 * 10^{4}\right)$ & $16.44( \pm 0.12)$ & $6.06( \pm 0.46)$ & $8.25 * 10^{3}$ \\
\hline 28.31 & $16.81( \pm 0.14)$ & $5.13 * 10^{5}\left( \pm 4.76 * 10^{4}\right)$ & $15.7( \pm 0.06)$ & $9.79( \pm 0.36)$ & $2.62 * 10^{3}$ \\
\hline 38.14 & $16.20( \pm 0.04)$ & $7.84 * 10^{5}\left( \pm 2.01 * 10^{4}\right)$ & $16.23( \pm 0.08)$ & $6.96( \pm 0.34)$ & $5.63 * 10^{3}$ \\
\hline 40.85 & $15.86( \pm 0.06)$ & $1.00 * 10^{6}\left( \pm 4.25 * 10^{4}\right)$ & $15.04( \pm 0.08)$ & $15.13( \pm 0.77)$ & $3.30 * 10^{3}$ \\
\hline 32.58 & $15.51( \pm 0.16)$ & $1.28 * 10^{6}\left( \pm 1.40 * 10^{5}\right)$ & $15.98( \pm 0.06)$ & $8.16( \pm 0.36)$ & $7.84 * 10^{3}$ \\
\hline 33.29 & $16.20( \pm 0.06)$ & $7.87 * 10^{5}\left( \pm 3.61 * 10^{4}\right)$ & $13.89( \pm 0.06)$ & $31.95( \pm 1.19)$ & $1.23 * 10^{3}$ \\
\hline 34.82 & $14.88( \pm 0.35)$ & $2.02 * 10^{6}\left( \pm 5.24 * 10^{5}\right)$ & $15.62( \pm 0.05)$ & $10.31( \pm 0.29)$ & $9.80 * 10^{3}$ \\
\hline 55.12 & $17.64( \pm 0.03)$ & $2.87 * 10^{5}\left( \pm 6.40 * 10^{3}\right)$ & $14.9( \pm 0.01)$ & $16.49( \pm 0.03)$ & $8.70 * 10^{2}$ \\
\hline 31.53 & $18.32( \pm 0.07)$ & $1.78 * 10^{5}\left( \pm 8.22 * 10^{3}\right)$ & $15.52( \pm 0.02)$ & $11( \pm 0.10)$ & $8.09 * 10^{2}$ \\
\hline 44.22 & $15.68( \pm 0.16)$ & $1.13^{*} 10^{6}\left( \pm 1.24 * 10^{5}\right)$ & $15.66( \pm 0.04)$ & $10.08( \pm 0.23)$ & $5.61 * 10^{3}$ \\
\hline 25.76 & $16.11( \pm 0.17)$ & $8.43 * 10^{5}\left( \pm 9.61 * 10^{4}\right)$ & $15.6( \pm 0.06)$ & $10.49( \pm 0.37)$ & $4.02 * 10^{3}$ \\
\hline 29 & $17.53( \pm 0.08)$ & $3.09 * 10^{5}\left( \pm 1.67 * 10^{4}\right)$ & $16.26( \pm 0.03)$ & $6.83( \pm 0.13)$ & $2.26 * 10^{3}$ \\
\hline
\end{tabular}




\begin{tabular}{|c|c|c|c|c|c|}
\hline 30.65 & $15.22( \pm 0.06)$ & $2.02 * 10^{6}\left( \pm 8.34 * 10^{4}\right)$ & $15.57( \pm 0.11)$ & $9.95( \pm 0.76)$ & $1.02 * 10^{4}$ \\
\hline 15.88 & $16.05( \pm 0.05)$ & $1.14 * 10^{6}\left( \pm 3.96 * 10^{4}\right)$ & $15.81( \pm 0.08)$ & $8.45( \pm 0.40)$ & $6.75 * 10^{3}$ \\
\hline 57.1 & $17.05( \pm 0.02)$ & $5.65 * 10^{5}\left( \pm 5.37 * 10^{3}\right)$ & $15.19( \pm 0.07)$ & $12.71( \pm 0.60)$ & $2.22 * 10^{3}$ \\
\hline 19.91 & $16.40( \pm 0.06)$ & $8.91 * 10^{5}\left( \pm 3.89 * 10^{4}\right)$ & $15.90( \pm 0.10)$ & $7.97( \pm 0.51)$ & $5.59 * 10^{3}$ \\
\hline
\end{tabular}


Table 3. Reproducibility test for quantification of a) ' $\mathrm{Ca}$. Phytoplasma mali' GU and b) pg of insect $18 \mathrm{~S}$ rDNA fragment.

a)

\begin{tabular}{|c|c|c|c|}
\hline Samples & $\begin{array}{c}\text { Mean } \\
\text { GU }\end{array}$ & SD & CV\% \\
\hline P12 & $2.63 * 10^{6}$ & $1.28 * 10^{4}$ & 4.73 \\
\hline P5 & $3.13 * 10^{6}$ & $2.10 * 10^{5}$ & 7.11 \\
\hline P23 & $2.88 * 10^{6}$ & $7.16^{*} 10^{4}$ & 2.59 \\
\hline P15 & $2.36 * 10^{6}$ & $1.44 * 10^{5}$ & 6.31 \\
\hline P8 & $2.84 * 10^{6}$ & $1.90 * 10^{5}$ & 6.98 \\
\hline P20 & $2.49 * 10^{6}$ & $3.03 * 10^{5}$ & 13.63 \\
\hline P9 & $3.07 * 10^{6}$ & $1.90 * 10^{5}$ & 6.10 \\
\hline
\end{tabular}

b)

\begin{tabular}{|c|c|c|c|}
\hline Samples & $\begin{array}{c}\text { Mean } \\
\text { pg }\end{array}$ & SD & CV\% \\
\hline $\mathrm{C} 2$ & 14.24 & 0.82 & 5.80 \\
\hline $\mathrm{C} 4$ & 17.49 & 0.47 & 2.74 \\
\hline $\mathrm{C} 20$ & 12.51 & 1.02 & 8.2 \\
\hline $\mathrm{C} 13$ & 2.74 & 0.15 & 5.39 \\
\hline $\mathrm{C} 11$ & 22.76 & 1.35 & 5.88 \\
\hline $\mathrm{C} 9$ & 8.37 & 0.36 & 4.38 \\
\hline $\mathrm{C} 13$ & 14.83 & 0.43 & 2.85 \\
\hline
\end{tabular}


Table 4. Repeatability test for quantification of a) ' $\mathrm{Ca}$. Phytoplasma mali' GU and b) pg of insect $18 \mathrm{~S}$ rDNA fragment.

a)

\begin{tabular}{|c|c|c|c|}
\hline Samples & $\begin{array}{c}\text { Mean } \\
\text { GU }\end{array}$ & SD & CV\% \\
\hline 1 & $2.84 * 10^{6}$ & $1.82 * 10^{5}$ & 6.4 \\
\hline 2 & $3.55 * 10^{6}$ & $1.54 * 10^{5}$ & 4.3 \\
\hline 3 & $3.26 * 10^{6}$ & $5.94 * 10^{4}$ & 1.8 \\
\hline 4 & $2.78 * 10^{6}$ & $1.38 * 10^{5}$ & 4.9 \\
\hline 5 & $3.15 * 10^{6}$ & $1.29 * 10^{5}$ & 4.1 \\
\hline 6 & $2.98 * 10^{6}$ & $1.85 * 10^{5}$ & 6.2 \\
\hline 7 & $3.15 * 10^{6}$ & $2.87 * 10^{5}$ & 9.1 \\
\hline
\end{tabular}

b)

\begin{tabular}{|c|c|c|c|}
\hline Samples & $\begin{array}{c}\text { Mean } \\
\text { pg }\end{array}$ & SD & CV\% \\
\hline 1 & 14.05 & 0.89 & 6.3 \\
\hline 2 & 16.9 & 0.76 & 4.5 \\
\hline 3 & 12.21 & 1.23 & 10.1 \\
\hline 4 & 2.95 & 0.11 & 3.6 \\
\hline 5 & 23.74 & 1.6 & 6.7 \\
\hline 6 & 7.77 & 0.49 & 6.26 \\
\hline 7 & 15.4 & 0.59 & 3.8 \\
\hline
\end{tabular}

